\title{
Allergy to laboratory animals: a retrospective and a prospective study
}

\author{
G E DAVIES, ${ }^{1}$ AUDREY V THOMPSON,${ }^{1} \mathrm{Z}$ NIEWOLA, ${ }^{1} \mathrm{G}$ E BURROWS, ${ }^{2}$ \\ E L TEASDALE, ${ }^{2}$ DOROTHY J BIRD, ${ }^{2}$ AND DOROTHY A PHILLIPS ${ }^{2}$
}

From Central Toxicology Laboratory ${ }^{1}$ and Occupational Health Department, Pharmaceuticals Division, ${ }^{2}$ Imperial Chemical Industries plc, Alderley Park, Macclesfield, Cheshire SK10 4TJ, UK

ABSTRACT Twenty four volunteers who had been allergic to laboratory animals for some years were examined by means of a questionnaire paying particular attention to symptoms associated with rats and by serological and skin tests with extracts of rat urine (retrospective study). Nasal and eye symptoms were reported by 21 and 16 individuals respectively: 13 had asthma. Positive skin tests and high levels of specific IgE antibody to rat urine extract were found in 17 of the more severely affected individuals and this group included 12 of those with asthma. Latent periods of work with animals before symptoms appeared varied from 0.5 to 12 years. Also 148 individuals were studied during their first year of work with animals (prospective study). Symptoms developing during the year were reported by $15 \%$, asthma by $2 \%$. IgE antibody levels to rat urine were raised in $40 \%$ of affected and $6 \%$ of the unaffected individuals but there was no significant correlation between symptoms and either antibody levels or positive skin tests. Allergic symptoms developing during the first year of postemployment were, on the whole, much milder than those seen in the retrospective study. A tentative conclusion is that most individuals who become allergic to laboratory animals develop the condition in a mild form during their first year of employment but it appears probable that atopic individuals, although having an equal chance of developing allergy as compared with non-atopic individuals, may eventually progress to a more severe form of the disease.

Allergy to laboratory animals (ALA), after a period of relative neglect, is now receiving increased attention $^{1-10}$. While all authors agree that the overall incidence of ALA in the exposed population is about $20 \%$, there is considerable variation in terms of the percentage of individuals with ALA (table 1).

A notable advance in the study of ALA resulted from the findings of Newman-Taylor et al ${ }^{11}$ and Longbottom $^{12}$ that a major allergen is found in the urine of rats and mice. Among other benefits these findings have facilitated the use of relevant immunological approaches to the problems presented by ALA.

Despite our increased knowledge, more information is needed before a rational approach to the control of ALA can be instituted. The present study had two main aims: (1) to investigate the correlation between immunological tests and the presence of

Received 15 June 1982

Accepted 15 November 1982 symptoms in a group of people with established allergy to rats and (2) to study the nature and rate of development of allergy during the period of employment as an animal worker. A subsidiary aim of the study was to offer an explanation for the apparently wide differences in the reported incidence of asthma. The present paper describes our initial findings, and is presented in two parts, a retrospective study and a prospective study.

The retrospective study attempted to correlate rat associated allergic symptoms with the presence of specific IgE antibody and the response in skin tests to rat urine. The volunteers included in this study were selected solely on the basis of their previous report of allergic symptoms. ${ }^{8}$ Although some of them reported symptoms in association with a variety of species, we decided to concentrate this part of the study on rat associated allergy alone since an acceptable RAST procedure was at the time available only for rat urine.

In the prospective study we determined incidence of ALA in one year. For the reason given above IgE 
Table 1 Reported incidence of allergy to laboratory animals

\begin{tabular}{|c|c|c|c|c|}
\hline \multirow[t]{2}{*}{ Author } & \multirow{2}{*}{$\begin{array}{l}\text { No of animal } \\
\text { workers surveyed }\end{array}$} & \multirow[t]{2}{*}{$\%$ with $A L A$} & \multicolumn{2}{|l|}{ Asthma } \\
\hline & & & $\%$ of total & $\begin{array}{l}\% \text { of } A L A \\
\text { individuals }\end{array}$ \\
\hline $\begin{array}{l}\text { Lincoln et al } \\
\text { Lutsky and Newman } \\
\text { Taylor } \text { et }^{2} l^{3} \\
\text { Lutsky and Toshner } \\
\text { Gross } \\
\text { Cockroft et al } \\
\text { Slovak and Hill' } \\
\text { Davies and McArdle } \\
\text { Newman Taylor et } a l^{9} \\
\text { Orr }\end{array}$ & $\begin{array}{r}238 \\
1300 \\
474 \\
- \\
399 \\
179 \\
146 \\
585 \\
144 \\
68\end{array}$ & $\begin{array}{l}11 \\
15 \\
23 \\
15 \\
27 \\
30 \\
20 \\
27 \\
22\end{array}$ & $\begin{array}{r}5 \\
10 \\
9 \\
-7 \cdot 5 \\
12 \\
10 \\
3 \\
11 \\
4\end{array}$ & $\begin{array}{l}48 \\
71 \\
39 \\
56 \\
51 \\
44 \\
31 \\
16 \\
30 \\
20\end{array}$ \\
\hline
\end{tabular}

antibody only to rat urine was measured but, fortuitously, rats were the sole species to which all had been exposed in common. In this study any relevant symptom, not necessarily associated with rats alone, which appeared during the year was taken into account.

\section{Materials and methods}

\section{ESTIMATION OF TOTAL IgE LEVELS}

Serum IgE (PRIST) assays were carried out in accordance with the details given by the manufacturers (Pharmacia Diagnostics, Uppsala, Sweden).

\section{RAT URINARY ALLERGEN}

Urine was collected daily from male rats aged 3-4 months and stored at $-20^{\circ} \mathrm{C}$. When one litre had been collected the urine was thawed, centrifuged at $2500 \mathrm{G}$ for 15 minutes and dialysed for 48 hours against four changes of $0.05 \mathrm{M}$ ammonium bicarbonate and freeze dried. The rat urinary extract used in our experiments was relatively free from serum proteins (fig 1). The material used to prepare the rat urinary skin test reagent, however, was that described by Longbottom ${ }^{12}$ and contained rather more serum protein.

\section{ESTIMATION OF IgE ANTIBODY TO RAT URINARY ALLERGENS}

IgE antibodies to rat urinary allergens were measured by a modification of the RAST described by Ceska et al.$^{13}$ Rat urine extract $(20 \mathrm{mg})$ was added to $1 \mathrm{~g}$ of cyanogen bromide-activated Whatman No 1 filter paper discs suspended in $20 \mathrm{ml}$ of $0.1 \mathrm{M}$ sodium bi-carbonate $/ 0.5 \mathrm{M}$ sodium chloride buffer $\mathrm{pH} 8 \cdot 0$. After mixing at $4^{\circ} \mathrm{C}$ for 72 hours the supernatant was removed and replaced by $20 \mathrm{ml}$ of $1.0 \mathrm{M}$ $\beta$-ethanolamine, $\mathrm{pH} 8 \cdot 0$. After further mixing at $4^{\circ} \mathrm{C}$ for $16-24$ hours the discs were washed thoroughly with bicarbonate/chloride buffer, then with distilled water, and finally with phosphate buffered saline ( $\mathrm{pH}$ 7.6) containing sodium azide
$(0 \cdot 05 \%)$. They were stored at $-20^{\circ} \mathrm{C}$ until required for use.

RAST tests were carried out by adding $50 \mu \mathrm{l}$ of rabbit antihuman IgE ${ }^{125}$ I (Pharmacia Diagnostics, Uppsala, Sweden) to the discs. Control tubes consisted of (a) $50 \mu \mathrm{l}$ of a known positive, (b) $50 \mu \mathrm{l}$ known negative, and (c) $50 \mu$ phosphate buffered saline. After overnight at room temperature the
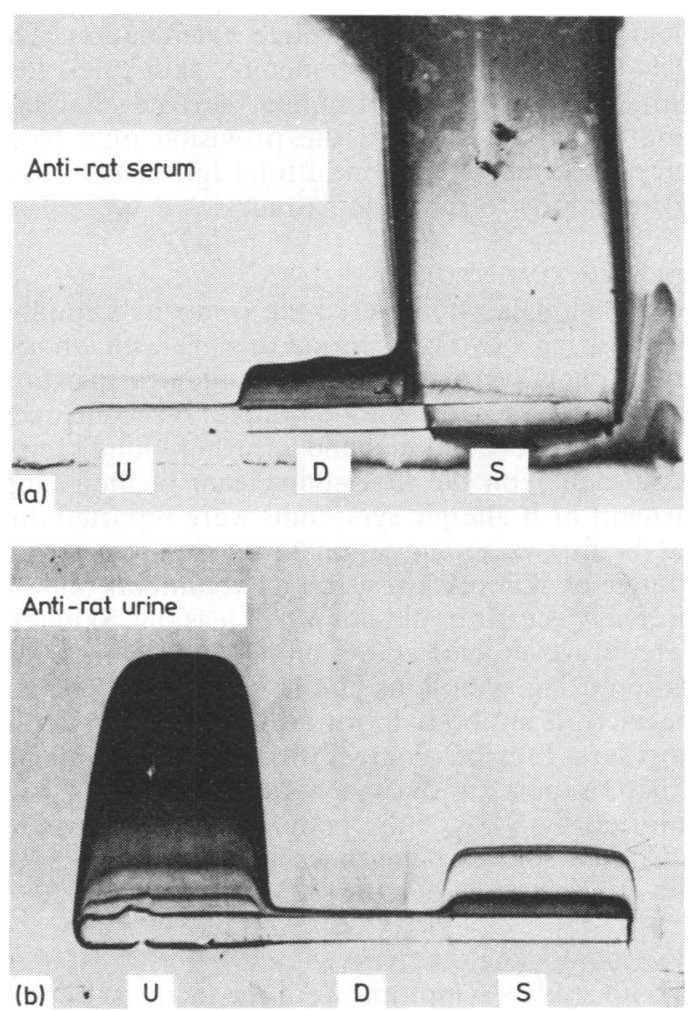

Fig 1 Line immunoelectrophoresis into: (a) rabbit antirat serum, (b) rabbit antirat urine: $U$ (urine $1 \mathrm{mg} / \mathrm{ml}$ ), $D$ (dander $2 \mathrm{mg} / \mathrm{ml}$ ), $S$ (serum 1:2). 
discs were all washed for $3 \times 30$ minute periods and the radioactivity determined with a 1270 Rackgamma II gamma counter (LKB, Finland). Antibody levels were expressed in terms of the percentage of the added total radioactivity bound to the discs.

\section{SKIN PRICK TESTS}

Skin prick tests were done on the volar aspect of the forearm, using the following materials, which were all supplied by Bencard Limited through the kindness of Dr J Dewdney: control solution; Grp B2 (pollens) grasses $(2.5 \%)$; Dermatophagoides pteronyssinus $(1.2 \%)$; cat fur $(150 \%)$; dog hair $(150 \%)$; guinea pig hair $(6 \%)$; mouse hair $(6 \%)$; rabbit fur $(150 \%)$; rat hair $(6 \%)$; guinea pig serum $(1.0 \mathrm{mg} / \mathrm{ml}) ;$ mouse serum $(1.0 \mathrm{mg} / \mathrm{ml}) ;$ rabbit serum $(1.0 \mathrm{mg} / \mathrm{ml}) ;$ rat serum $(1.0 \mathrm{mg} / \mathrm{ml})$; guinea pig urine $(0.1 \mathrm{mg} / \mathrm{ml}) ;$ mouse urine $(0.1 \mathrm{mg} / \mathrm{ml})$; rabbit urine $(0 \cdot 1 \mathrm{mg} / \mathrm{ml})$; rat urine $(0 \cdot 1 \mathrm{mg} / \mathrm{ml})$.

\section{RETROSPECTIVE STUDY}

Thirty two individuals, who in a previous study ${ }^{8}$ had reported allergic symptoms, volunteered to submit themselves to a more complete examination. This included a detailed questionnaire, skin prick tests with environmental and animal derived allergens, lung function tests, and the provision of a blood sample for the estimation of total IgE levels and of $\mathrm{IgE}$ antibody to rat urine extract.

\section{PROSPECTIVE STUDY}

All individuals who entered the company's employment during a two year period to work with laboratory animals were invited to complete a questionnaire and to provide a blood sample. A second questionnaire was completed and a further blood sample taken either on the first anniversary of their employment or if allergic symptoms were reported during the first year. The original intention to carry out a range of skin prick tests on all volunteers on both interview occasions did not prove feasible. Skin tests were, however, carried out on most of the individuals reporting symptoms and levels of total $\operatorname{IgE}$ and specific IgE antibody to rat urine were estimated in most sera. Previous contact with laboratory animals, either as pets or during work as a student, was reported by $54 \%$ of the population, the values for individual species being mice, $22 \%$; rabbits, $27 \%$; rats, $25 \%$; and guinea pigs, $25 \%$.

\section{SYMPTOM EVALUATION}

In both studies symptoms were recorded as: "nasal" (stuffy or blocked nose; repeated attacks of sneezzing); "eyes" (smarting, itchy); "skin" (rash, eczema); or "chest" (asthma). Severity was graded as 1 (mild), 2 (moderate), or 3 (severe).

It should be emphasised that in the retrospective study "symptoms" refer only to those which were stated by the individual concerned to be associated with exposure to rats, whereas in the prospective study all allergic symptoms which appeared during the year of study were included.

\section{Results}

\section{BASE-LINE VALUES OF IgE ANTIBODY}

One hundred and forty two assays for specific IgE antibody to rat urine were carried out on serum samples obtained at first interview: $96 \%$ showed less than $3 \%$ binding and this figure was therefore taken as the base line value (fig 2). Not included in this figure are two individuals who were found to have high levels of antibody at first interview (19.8\% and $21.1 \%$ respectively). Both these individuals were highly atopic but neither has so far developed symtoms attributable to animal allergy.

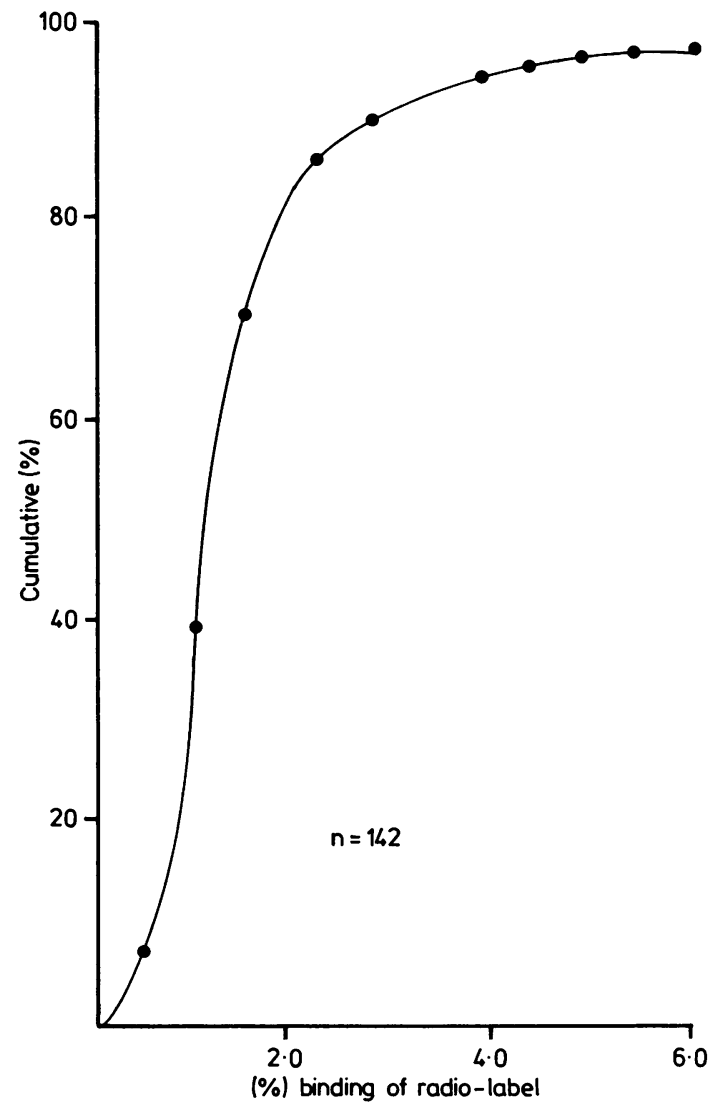

Fig 2 Distribution of specific IgE to rat urine in individuals at time of first interview. 


\section{RETROSPECTIVE STUDY}

Twenty four of the 32 volunteers reported allergic symptoms which they associated with contact with rats: nasal and eye symptoms were the commonest, being reported by 21 and 16 individuals repectively; 13 had chest symptoms and there were skin complaints in 11. Table 2 shows the findings obtained with 17 individuals, 16 of whom had rat associated and one mouse associated symptoms and $\operatorname{IgE}$ antibody to rat urine in their serum with a binding capacity greater than $3 \%$. All 17 had positive skin prick test reactions to rat urine; 10 were atopic and 10 (including seven of the atopics) were also allergic to other laboratory animals. Latent period before

Table 2 Retrospective study. Individuals having serum IgE antibody to rat urine with a binding capacity of more than $2.9 \%$

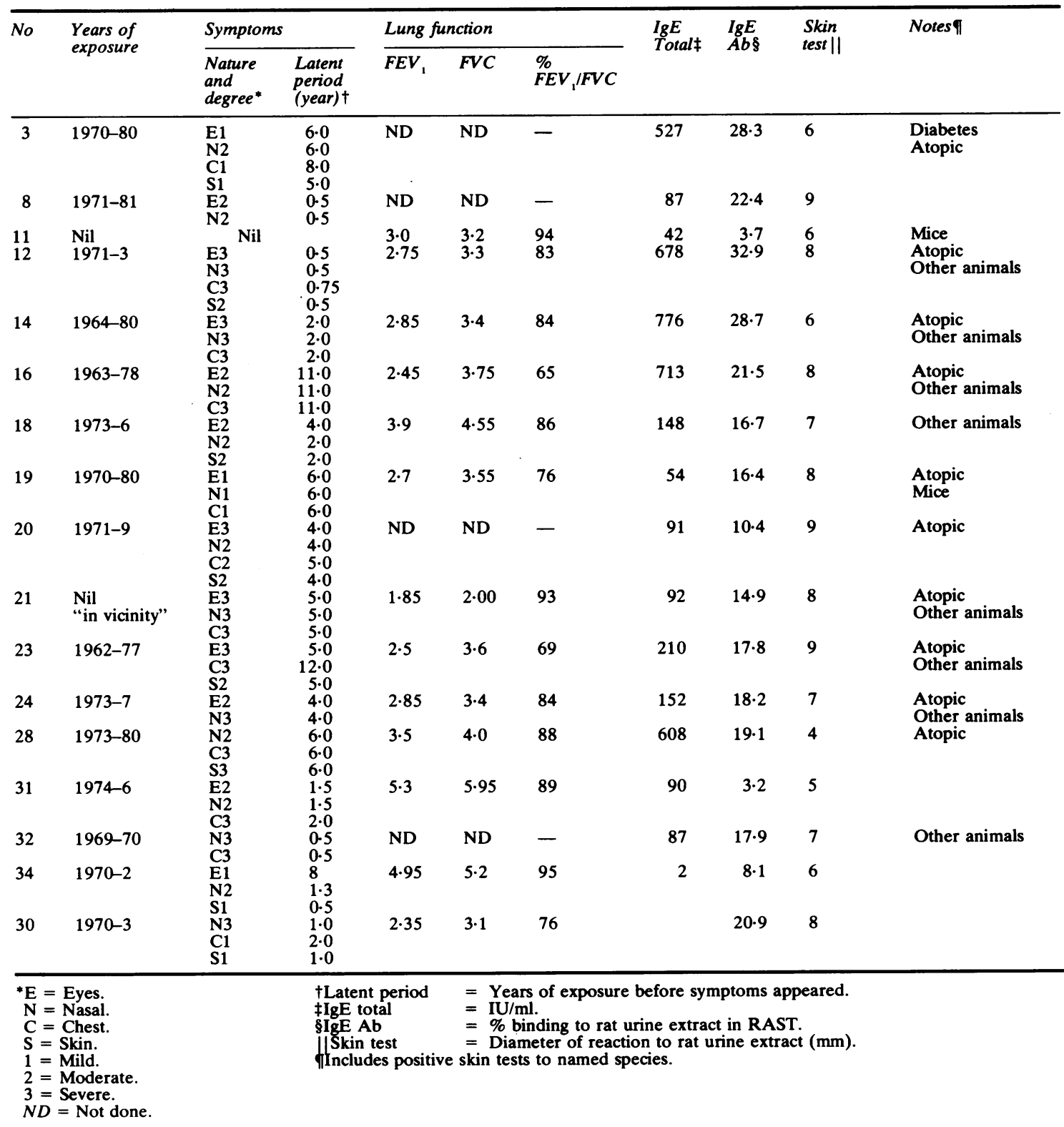


appearance of symptoms varied from 0.5 to 12 years. Twelve of the 13 with chest symptoms were in this "high antibody" group.

Eight volunteers reported rat associated symptoms but their sera did not contain significant levels of IgE antibody to rat urine (table 3); five were skin tested, three of whom showed positive reactions to rat urine; two were atopic; one was also sensitive to mice and one to guinea pigs.

Seven volunteers had no current symptoms associated with rats, although they had reported symptoms in the previous survey; ${ }^{8}$ none had significant levels of IgE antibody to rat urine and none showed positive skin prick test reactions to rat urine; two were atopic and three allergic to other species (table 4).

Neither total IgE levels nor the results of lung function tests were correlated with ALA. More sites were affected and the severity of symptoms were greater in those individuals with the higher levels of antibody. Chest symptoms, too, were more common in this group.

\section{PROSPECTIVE STUDY}

So far 148 individuals have entered the study: five $(3.4 \%)$ reported the development of allergic symptoms before the completion of their first year's employment and another 17 reported symptoms at their anniversary interview, giving a total incidence of $14.9 \%$. With one exception rats were the only species to which all the affected individuals had been exposed (table 5). Of the people with postemployment symptoms, nine sera bound $3 \%$ or more of the labelled anti-IgE (3-26\%) and 13 bound less than $3 \%(0 \cdot 5-2 \cdot 8 \%)$. The distribution of affected sites, the mean severity, and the incidence of positive skin reactions to rat urine were not significantly different in the two groups $(p>0 \cdot 1)$. Two in the first group and one in the second developed asthma (an overall incidence of $2 \%$, or $14 \%$ of those with symptoms). Eleven of the 17 tested gave positive skin reactions to grass pollen or $D$ pteronyssinus or both. Response to skin tests with other animal allergens were wide and varied and will be reported as part of a separate study. When

Table 3 Retrospective study. Individuals having serum IgE antibody to rat urine with a binding capacity of less than $3 \%$

\begin{tabular}{|c|c|c|c|c|c|c|c|c|c|c|}
\hline \multirow[t]{2}{*}{ No } & \multirow{2}{*}{$\begin{array}{l}\text { Years of } \\
\text { exposure }\end{array}$} & \multicolumn{2}{|c|}{ Symptoms } & \multicolumn{3}{|c|}{ Lung function } & \multirow{2}{*}{$\begin{array}{l}\text { IgEE } \\
\text { Total }\end{array}$} & \multirow{2}{*}{$\begin{array}{l}I g E \\
A b\end{array}$} & \multirow{2}{*}{$\begin{array}{l}\text { Skin } \\
\text { test }\end{array}$} & \multirow[t]{2}{*}{ Notes } \\
\hline & & $\begin{array}{l}\text { Nature } \\
\text { and } \\
\text { degree }\end{array}$ & $\begin{array}{l}\text { Latent } \\
\text { period } \\
\text { (year) }\end{array}$ & $F E V_{1}$ & $F V C$ & $\%$ & & & & \\
\hline $\begin{array}{l}5 \\
1\end{array}$ & $\begin{array}{l}1972-80 \\
1975-80\end{array}$ & $\begin{array}{l}\text { N1 } \\
\text { E2 } \\
\text { N2 } \\
\text { C2 }\end{array}$ & $\begin{array}{l}4.0 \\
1.5 \\
1.5 \\
1.5\end{array}$ & $\begin{array}{l}2.7 \\
3.05\end{array}$ & $\begin{array}{l}3 \cdot 0 \\
3 \cdot 45\end{array}$ & $\begin{array}{l}90 \\
88\end{array}$ & $\begin{array}{r}3 \\
210\end{array}$ & $\begin{array}{l}0.8 \\
1.9\end{array}$ & $\begin{array}{l}0 \\
0\end{array}$ & \\
\hline $\begin{array}{r}2 \\
17\end{array}$ & $\begin{array}{l}1957-80 \\
1976-80\end{array}$ & $\begin{array}{l}\text { S1 } \\
\text { E1 } \\
\text { N1 }\end{array}$ & $\begin{array}{l}1.0 \\
0.5 \\
0.5\end{array}$ & $\begin{array}{l}2 \cdot 6 \\
2 \cdot 7\end{array}$ & $\begin{array}{l}3 \cdot 4 \\
3 \cdot 3\end{array}$ & $\begin{array}{l}76 \\
82\end{array}$ & $\begin{array}{r}316 \\
3\end{array}$ & $\begin{array}{l}2 \cdot 0 \\
1 \cdot 2\end{array}$ & $\begin{array}{l}4 \\
4\end{array}$ & $\begin{array}{l}\text { Atopic } \\
\text { Mice }\end{array}$ \\
\hline $\begin{array}{l}22 \\
25 \\
27\end{array}$ & $\begin{array}{l}1960-80 \\
1974-80 \\
1957-77\end{array}$ & $\begin{array}{l}\text { N1 } \\
\text { N2 } \\
\text { E2 } \\
\text { N2 } \\
\text { S2 }\end{array}$ & $\begin{array}{r}16.0 \\
0.2 \\
7.0 \\
7.0 \\
7.0\end{array}$ & $\begin{array}{l}4 \cdot 55 \\
2.75 \\
3 \cdot 3\end{array}$ & $\begin{array}{l}7.0 \\
3.6 \\
3.9\end{array}$ & $\begin{array}{l}65 \\
76 \\
85\end{array}$ & $\begin{array}{r}33 \\
4 \\
81\end{array}$ & $\begin{array}{l}1 \cdot 1 \\
1 \cdot 2 \\
2 \cdot 4\end{array}$ & $\begin{array}{l}\mathrm{ND} \\
2 \\
\mathrm{ND}\end{array}$ & $\begin{array}{l}\text { Atopic } \\
\text { Guinea pigs }\end{array}$ \\
\hline
\end{tabular}

See footnote to table 2 for key to symbols.

Table 4 Retrospective study. Individuals with no symptoms

\begin{tabular}{|c|c|c|c|c|c|c|c|c|c|c|}
\hline \multirow[t]{2}{*}{ No } & \multirow{2}{*}{$\begin{array}{l}\text { Years of } \\
\text { exposure }\end{array}$} & \multicolumn{2}{|c|}{ Symptoms } & \multicolumn{3}{|c|}{ Lung function } & \multirow{2}{*}{$\begin{array}{l}\text { IgE } \\
\text { Total }\end{array}$} & \multirow{2}{*}{$\begin{array}{l}\lg E \\
A b\end{array}$} & \multirow{2}{*}{$\begin{array}{l}\text { Skin } \\
\text { test }\end{array}$} & \multirow[t]{2}{*}{ Notes } \\
\hline & & $\begin{array}{l}\text { Nature } \\
\text { and } \\
\text { degree }\end{array}$ & $\begin{array}{c}\text { Latent } \\
\text { period } \\
\text { (year) }\end{array}$ & $F E V_{1}$ & $F V C$ & $\%$ & & & & \\
\hline $\begin{array}{l}4 \\
6\end{array}$ & $\begin{array}{l}1970-80 \\
1975-81\end{array}$ & - & 二 & $\begin{array}{l}4.55 \\
3.75\end{array}$ & $\begin{array}{l}6 \cdot 10 \\
4 \cdot 2\end{array}$ & $\begin{array}{l}75 \\
89\end{array}$ & $\begin{array}{r}118 \\
17\end{array}$ & $\begin{array}{l}1 \cdot 7 \\
1 \cdot 1\end{array}$ & $\begin{array}{l}0 \\
0\end{array}$ & \multirow{2}{*}{$\begin{array}{l}\text { Atopic } \\
\text { Other animals } \\
\text { Rabbits } \\
\text { Atopic } \\
\text { Hamster }\end{array}$} \\
\hline $\begin{array}{r}7 \\
9 \\
10 \\
13 \\
15\end{array}$ & $\begin{array}{l}1978-81 \\
1979-8 \\
\text { Nil } \\
1971-4 \\
1970-81\end{array}$ & $\begin{array}{l}z \\
z \\
z\end{array}$ & $\begin{array}{l}\bar{z} \\
\bar{z}\end{array}$ & $\begin{array}{l}3 \cdot 45 \\
4 \cdot 75 \\
3 \cdot 3 \\
4 \cdot 25 \\
3 \cdot 4\end{array}$ & $\begin{array}{l}3.7 \\
5.6 \\
3.9 \\
4.9 \\
3.7\end{array}$ & $\begin{array}{l}93 \\
85 \\
85 \\
87 \\
92\end{array}$ & $\begin{array}{r}6 \\
110 \\
61 \\
16 \\
31\end{array}$ & $\begin{array}{l}1 \cdot 0 \\
2 \cdot 1 \\
1 \cdot 1 \\
2 \cdot 4 \\
0 \cdot 8\end{array}$ & $\begin{array}{l}0 \\
0 \\
0 \\
0 \\
0\end{array}$ & \\
\hline
\end{tabular}

See footnote to table 2 for key to symbols. 
Table 5 Allergic symptoms developed during first year of employment: relationship between postemployment symptoms and immune reactions to rat urine

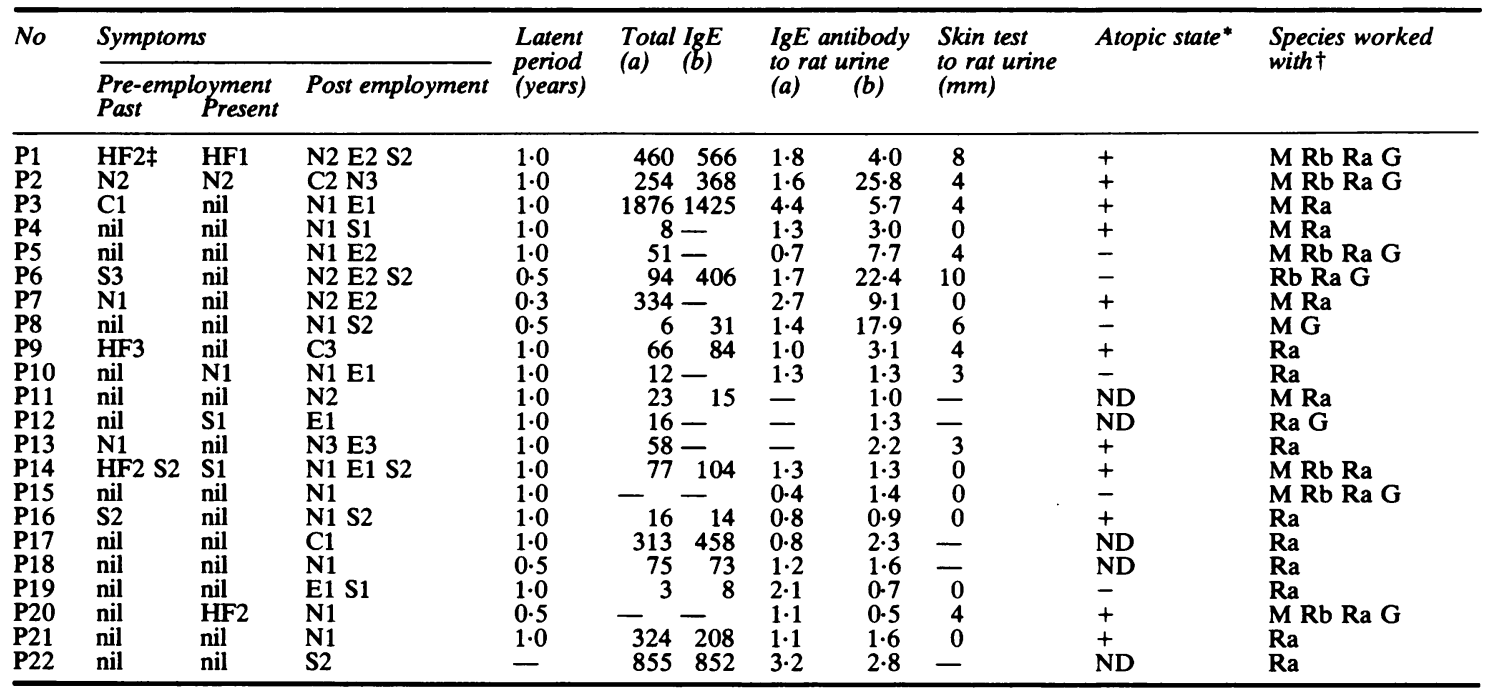

$(a)=1$ st estimate; $(b)=2$ nd estimate at end of latent period.

Atopic state $-+=$ Positive skin prick test to one or more environmental allergen.

+ Species: $\mathbf{M}=$ mouse, $\mathbf{R} \mathbf{b}=$ rabbit, $\mathbf{R a}=$ rat, $\mathbf{G}=$ guinea pig.

See footnote to table 2 for key to other symbols.

$\ddagger$ HF $=$ Hay fever.

Table 6 Prospective study: summary of finding (2)

\begin{tabular}{|c|c|c|c|c|}
\hline \multirow[t]{2}{*}{ Group } & \multirow[t]{2}{*}{ No } & \multicolumn{3}{|l|}{$\%$} \\
\hline & & Of total & Of symptomatics & Of non-symptomatics \\
\hline $\begin{array}{l}\text { Symptomatic } \\
\text { Symptomatic }(A b>2.9 \%) \\
\text { Symptomatic }(A b<3.0 \%) \\
\text { Non-symptomatic } \\
\text { Non-symptomatic }(A b>2.9 \%) \\
\text { Non-symptomatic }(\mathrm{Ab}<3.0 \%)\end{array}$ & $\begin{array}{r}22 \\
9 \\
13 \\
126 \\
7 \\
119\end{array}$ & $\begin{array}{r}14 \cdot 9 \\
6 \cdot 1 \\
8 \cdot 8 \\
85 \cdot 1 \\
4 \cdot 7 \\
-\end{array}$ & $\begin{array}{l}100 \cdot 0 \\
40 \cdot 9 \\
59 \cdot 1 \\
- \\
-\end{array}$ & $\begin{array}{l}- \\
\overline{-} \\
100 \\
5 \cdot 6 \\
94 \cdot 4\end{array}$ \\
\hline
\end{tabular}

*Postemployment symptoms.

various subgroups are compared as shown in table 6 , interesting differences emerge. Higher antibody levels were found in $41 \%$ of symptomatic individuals but only $6 \%$ of asymptomatics. As a percentage of the total population, however, the incidence of raised antibody levels was not significantly greater in the symptomatic group. Total IgE levels bore no obvious relationship to the development of ALA. Seven of the 126 volunteers without ALA symptoms (4.7\%) developed high levels of IgE antibody to rat urine (and the four who were tested also gave positive skin reactions to rat urine) but no ALA was reported by them (table 7).

\section{Discussion}

The retrospective study has shown a good correla- tion between the presence of raised serum IgE antibodies to rat urine, positive skin prick test responses to this allergen, and the progression of rat associated symptoms. When no significant level of antibody could be detected the symptoms were milder and fewer sites were affected. These findings may be representative of a stabilised population, some of whom have continued to work with animals despite their allergic symptoms having been present for several years. Especially noteworthy is the high proportion of asthma and atopy in the "high antibody" group (12/17 and 10/17 respectively), only two of the asthmatics being non-atopic as judged by skin tests to grass pollen or $D$ pteronyssinus, or both. Latent periods before the appearance of symptoms varied widely (0.5-12 years). As also noted by Cockcroft $e t$ al, ${ }^{6}$ rhinitis preceded asthma and there was no instance of asthma alone. No evidence of 
Table 7 Individuals with high levels of IgE antibodies to rat urine but apparently without symptoms

\begin{tabular}{|c|c|c|c|c|c|}
\hline \multirow[t]{2}{*}{ No } & \multirow{2}{*}{$\begin{array}{l}\text { Pre-employment } \\
\text { symptoms }\end{array}$} & \multicolumn{2}{|c|}{ Total IgE } & \multicolumn{2}{|c|}{$\operatorname{Ig} E$ antibody } \\
\hline & & (a) & (b) & (a) & (b) \\
\hline $\begin{array}{l}\text { P23 } \\
\text { P24* } \\
\text { P25 } \\
\text { P26* } \\
\text { P27 } \\
\text { P28* } \\
\text { P29* }\end{array}$ & $\begin{array}{l}\text { HF1 } \\
\text { N1 } \\
\text { N2 } \\
\text { S1 } \\
\text { HF1 } \\
\text { nil } \\
\text { nil }\end{array}$ & $\begin{array}{r}29 \\
1200 \\
13 \\
3 \\
68 \\
7 \\
10\end{array}$ & $\begin{array}{r}678 \\
757 \\
1452 \\
65 \\
68 \\
17 \\
33\end{array}$ & $\begin{array}{r}0.7 \\
19.8 \\
0.9 \\
0.8 \\
1.5 \\
1.1 \\
0.5\end{array}$ & $\begin{array}{r}31 \cdot 4 \\
14 \cdot 9 \\
5 \cdot 9 \\
23 \cdot 3 \\
8 \cdot 0 \\
4 \cdot 2 \\
17 \cdot 6\end{array}$ \\
\hline \multicolumn{6}{|c|}{ *These four individuals were also skin tested with the following results: } \\
\hline Allergen & & $P 24$ & $P 26$ & P28 & P29 \\
\hline Grass pollen & & + & - & + & + \\
\hline$D$ pteronyssinus & & + & - & + & + \\
\hline Cat dander & & + & + & - & - \\
\hline Dog dander & & + & - & - & + \\
\hline Mouse dander & & - & - & + & + \\
\hline Rat dander & & - & + & + & + \\
\hline Guinea pig dander & & + & + & + & - \\
\hline Mouse urine & & + & + & + & + \\
\hline Rabbit urine & & + & - & - & + \\
\hline Rat urine & · & + & + & + & + \\
\hline Guinea pig urine & & + & + & - & + \\
\hline Mouse serum & & + & + & + & + \\
\hline Rabbit serum & & + & + & + & + \\
\hline Rat serum & & + & + & + & + \\
\hline Guinea pig serum & & + & + & + & + \\
\hline
\end{tabular}

$(a)=1$ st estimate $(b)=2$ nd estimate, at first anniversary.

See footnote to table 2 for key to other symbols.

increased antibody levels of the asthmatic group as compared to the rhinitic group was discernible, by contrast with the suggestion of Newman-Taylor et $a l,{ }^{9}$ and there was no indication of difference in the incidence of positive skin tests between the two groups as reported by Slovak and Hill. ${ }^{7}$ Most of the affected subjects had found fairly elementary personal protection (paper face mask, gloves, and gown) to be reasonably effective, although many of the subjects admitted that they now restricted their contact with animals.

The prospective study represents, as it were, the other end of the spectrum - the first appearance of allergy and the results raise several problems, solutions to which are not yet apparent.

In common with other authors we have shown that a significant proportion of exposed workers develop allergy during their first year of contact. It is apparent, however, that there must be a substantial degree of contact before sensitisation occurs since none of the 148 volunteers was initially allergic to animals despite the fact that $54 \%$ of them had had previous (limited) contact with animals. What has become apparent for the first time is that the severity of allergy developed during the first year is usually only slight or moderate and the incidence of asthma is considerably lower than it will probably become eventually. There was no significant correlation between the objective tests (IgE antibody and skin test to rat urine) and subjective reporting of symptoms. Although the proportion of affected individuals with high antibody levels was greater $(41 \%)$ than that of unaffected individuals with high antibody levels $(6 \%)$ there were, nevertheless, seven subjects with high antibody levels and (where done) positive skin tests but who were free of allergic symptoms. This group presents more of a problem than the group who were symptomatic with low antibody levels (in whom the levels may eventually increase) since the occurrence of high specific IgE antibody levels in the absence of symptoms cannot readily be explained, especially as in many instances there was an accompanying positive skin test to rat urine, indicating that mast cells, at least those in the skin, had become sensitised.

The vexed question of the relationship between pre-existing atopy and the tendency to develop ALA cannot be answered by the present study because of the failure to carry out skin tests with common allergens when volunteers entered the study. This omission is being rectified in a current study which is also continuing to monitor those individuals who have already developed ALA.

One of the stated objectives of this work was to account for the wide differences in the reported incidence of asthma as a symptom of ALA. In addition to the more obvious explanations (differences in methods of acquiring data and in diagnostic 
criteria) it would appear from the present study that an important variable is the length of time during which the members of the population have been engaged in animal work since the early acquired allergy is rarely manifested as asthma, whereas increasing exposure leads to an increase in the proportion of asthmatics, particularly in the atopic group.

\section{References}

' Lincoln TA, Bolton NE, Garrett AS. Occupational allergy to animal dander and sera. JOM 1974;16:465-9.

${ }^{2}$ Lutsky II, Neuman I. Laboratory animal dander allergy: I. An occupational disease. Ann Allergy 1975;35:201-5,

${ }^{3}$ Taylor G, Davies GE, Altounyan REC, et al. Allergic reactions to laboratory animals. Nature 1976;260:230.

4 Lutsky I, Toshner D. A review of allergic respiratory disease in laboratory animal workers. Lab Anim Sci 1978;28:751-6.

${ }^{5}$ Gross NJ. Allergy to laboratory animals: epidemiologic, clinical, and physiologic aspects, and a trial of cromolyn in its management. J Allergy Clin Immunol 1980;66:158-65.

${ }^{6}$ Cockcroft A, Edwards J, McCarthy P, Andersson N. Allergy in laboratory animal workers. Lancet 1981 ;ii:827-30.

' Stovak AJM, Hill RN. Laboratory animal allergy: a clinical survey of an exposed population. Br J Ind Med 1981;38:38-41.

8 Davies GE, McArdle LA. Allergy to laboratory animals: a survey by questionnaire. Int Archs Allergy Appl Immunol 1981;64:302-7.

' Newman-Taylor AJ, Myers JR, Longbottom JL, Spackman D, Slovak AJM. Immunological differences beteen asthma and other allergic reactions in laboratory animal workers. Thorax 1981;36:229.

${ }^{10}$ Orr R, quoted by Dewdney JM. Allergy induced by exposure to animals. J $R$ Soc Med 1981;74:928-32.

"Newman-Taylor AJ, Longbottom JL, Pepys J. Respiratory allergy to urine proteins of rats and mice. Lancet 1977;ii:847-9.

${ }^{12}$ Longbottom JL. Purification and characterization of allergens from the urines of mice and rats. In: Oehling A, Mathov E, Glazer I, eds. Advances in allergology and immunology. New York: Permagon Press, 1980;483-90.

${ }^{13}$ Ceska M, Eriksson R, Varga JM. Radioimmunosorbent assay of allergens. J Allergy Clin Immunol 1972;49:1-9. 